\title{
Influence of abiotic factors on biodiversity of the populations of bivalve molluscs of the Lower Zarafshan reservoirs
}

\author{
Khusniddin Boymurodov ${ }^{1,}$, Nodir Khasanov ${ }^{2}$ \\ ${ }^{1}$ Samarkand State University, Department of Ecology, 140104 Samarkand, Uzbekistan \\ ${ }^{2}$ Navoi State Pedagogical Institute, 210100 Navoi, Uzbekistan
}

\begin{abstract}
The length of the reservoir area on the banks of the Zarafshan River and the presence of all biotopes inhabited by molluscs of the Unionidae and Corbisulidae families have made the basin a comfortable aquatic ecosystem for molluscs. The influence of rivers and fisheries on the formation of the fauna of bivalve molluses in reservoirs is significant. We found that 10 species and 2 subspecies of bivalve molluscs were distributed in the Kuymazor reservoir and 8 species and 2 subspecies of bivalve molluscs in Shurkul. Reservoirs of Sinanodonta species are shown for the first time by us. These molluses belong to the ecological groups like peloreophilic, rheophilic and pelolimnophilic. In the water reservoirs of Uzbekistan, the spread of bivalve molluscs by groups has common features. In all water reservoirs, an ecological group called peloreophil prevails, but the species belonging to the ecological group atre different in different water bodies. Such species of pedloelphils as Sinanodonta gibba, S. orbicularis, Corbiculina tibetensis and $\mathrm{C}$. ferghanensis are predominantly found in rivers, fish farms, and water reservoirs. The most common species in the canals are Corbiculina tibetensis and $\mathrm{C}$. ferghanensis. The next frequent occurrence in water reservoirs is the ecological group of rheophiles.
\end{abstract}

The use of biological resources is a pressing issue humanity faced. One of the current problems is the study of the effect of abiotic factors on the biodiversity of bivalve molluscs in the Lower Zarafshan reservoirs.

Scientific works on the species composition and distribution, systematics, protection of molluscs of the family Unionidae and Corbisulidae were carried out by foreign scientists such as James H.Thorp, Alanp Covich, Aldridge, Bouchet, Huber Markus, Bogan; Annabelle Cuttelod researched on the cultivation of pearls in sectors of the economy, particularly in artificial water bodies; Maria Haws, Mamangke, Rahayu, Sata Yoshida Srie Rahayu conducted experiments in the sphere of these molluscs. Bogatov, Starobogatov studied bivalve molluscs in the CIS countries; Bogatov; Andreev, Alyohina, Panov, Yanovich, Rijinashvili A.L, Sintyurina A.V. Bigaliev A.B Kuzmenkin D.V. also conducted

\footnotetext{
${ }^{*}$ Corresponding author: Boymurodov1971@mail.ru
} 
investigations regarding these kind of molluscs [1,2,3]. Izzatullaev I.Z and Boymurodov Kh.T. conducted research on the inventory of bivalve molluscs in water bodies, to determine their distribution characteristics depending on the water basin, to study the current state of populations of rare and endemic species.

In our research 121 samples from the reservoirs were studied, including 422 molluscs. Samples of these molluscs are systematically studied in the works of Ploxinsky in 1970; Rijinashvili in 2005; Starobogatov, Izzatullaev in 1984, Izzatullaev, Boymurodov in 2009 in different methods.

In the lower reaches of the Zarafshan River, the influence of abiotic factors on the biodiversity in the populations of bivalve molluscs belonging to the Unionidae and Corbiculidae families from the Kuymazor and Shurkul reservoirs was studied, the following findings have been found.

The Kuyimozor Reservoir is located in Bukhara region between Kuymazor and Kagan railway stations. It was built in 1958 around one of the depths in the lower reaches of the Zarafshan River, with a water volume of 350 million meter 3 and an area of $17.3 \mathrm{~km}^{2}$. Water is supplied to the Kuymazor reservoir from the Zarafshan River through a special canal (18 $\mathrm{km}$ ), as well as the Amu-Bukhara canal, which carries $40 \mathrm{~m}^{3} / \mathrm{s}$ of water. Previous studies and our research have shown that 10 species and 2 subspecies of bivalve molluscs live in the Kuymazor reservoir, which belong to two families and 4 generations (Table 1).

Table 1. Density, distribution and ecological group of biodiversity in the populations of bivalve molluscs of Lower Zarafshan reservoirs ( $\mathrm{m} 2 / \mathrm{pcs}$ )

\begin{tabular}{|c|c|c|c|c|}
\hline № & Family and species & $\begin{array}{c}\text { Kuymozor } \\
\text { reservoir }\end{array}$ & $\begin{array}{l}\text { Surkul } \\
\text { reservoir }\end{array}$ & Ecological types \\
\hline \multicolumn{5}{|c|}{ Unionidae family } \\
\hline \multicolumn{5}{|c|}{ Sinanodonta offsprings } \\
\hline 1 & Sinanodonta.gibba & $2.1 \pm 0.3$ & - & Peloreophilus \\
\hline 2 & Sinanodonta.orbicularis & $1.5 \pm 0.2$ & $1.2 \pm 0.2$ & Peloreophilus \\
\hline \multirow[t]{2}{*}{3} & Sinanodonta.puerorum & $1.6 \pm 0.3$ & $1.3 \pm 0.2$ & Peloreophilus \\
\hline & Colletopterum offsprings & & & \\
\hline 4 & Colletopterum.bactrianum & $0.8 \pm 0.1$ & $0.7 \pm 0.1$ & Rheophil \\
\hline 5 & Colletopterum cyreum sogdianum & $2.6 \pm 0.5$ & $0.9 \pm 0.1$ & Rheophil \\
\hline 6 & Colletopterum ponderosum volgense & $1.1 \pm 0.1$ & $0.8 \pm 0.1$ & Pelolimnophil \\
\hline 7 & Colletopterum kokandicum & $0.3 \pm 0.2$ & - & \\
\hline \multicolumn{5}{|c|}{ Corbiculidae family } \\
\hline \multicolumn{5}{|c|}{ Corbicula offsprings } \\
\hline 8 & Corbicula cor & $1.8 \pm 0.1$ & $1.3 \pm 0.1$ & Peloreophilus \\
\hline 9 & Corbicula fluminalis & $1.8 \pm 0.3$ & $1.4 \pm 0.2$ & Peloreophilus \\
\hline 10 & Corbicula purpurea & $1.2 \pm 0.1$ & $1.1 \pm 0.2$ & Peloreophilus \\
\hline \multicolumn{5}{|c|}{ Corbiculina offsprings } \\
\hline 11 & Corbculina tibctensis & $2.9 \pm 0.4$ & $2.9 \pm 0.3$ & Peloreophilus \\
\hline \multirow[t]{2}{*}{12} & Corbculina ferghanensis & $2.6 \pm 0.3$ & $3.1 \pm 0.4$ & Peloreophilus \\
\hline & Total: & 12 & 10 & \\
\hline
\end{tabular}

Uonionidae family Sinanodonta seed, Sinanodonta gibba, S. orbicularis, S. puerorum are widespread in the upper reaches of the river in the gullies of the Kuymazor reservoir and are less common than other species. The distribution of the species is greatly influenced by aquatic environmental factors such as water flow, water clarity and rocky, sandy, muddy biatopes in the reservoir $[4,5,6]$. 
The influence of two factors on the distribution of Sinanodonta seed species in the reservoir is primarily due to the fact that the waters of the Zarafshan River and the Amudarya are deposited in the Kuymazor Reservoir [7,8]. With water and fish, the seeds species of Sinanodonta and Colletopterum have passed into the Kuymazor reservoir. Second, on the banks of the Zarafshan River and in the Kuymazor reservoir, white amur and other types of fish acclimatized. With these fish, China led to the spread of molluscs. This is because the hyloxides of Sinanodonta offsprings are parasitic in these fish. The species distributed in the reservoir have different densities. Sinanodonta gibba averaged 2.1 per $1 \mathrm{~m}^{2}$, S. orbicularis 1.5, and S. puerorum 1.6. Fluctuations in the water level in the reservoir affect the distribution of bivalve molluscs.

No species belonging to the family Euglesidae and Pisididae were found in the Kuymazor reservoir because these species live in springs. and spread to the surrounding water types. Among these species, the density of the C. cyreum sogdianum species is 2.6 per $1 \mathrm{~m}^{2}$ larger than that of other species. We observed that the density of the remaining species Colletopterum ponderosum volgense ranged from 0.8 to 1.3. Corbicula cor, $C$. fluminalis, $C$. purpurea, Corbiculina ferghanensis, C. tibetensis from molluscs live in the inflow part of the reservoir, on the left bank and in the drainage channel. In general, molluscs are abundant in the mud-covered parts of the reservoir and where microphytes are abundant. Here they live at a depth of 2-4.5 $\mathrm{m}$ in areas with a lot of reeds and algae, and sometimes even in sandy, rocky places. Their density per $1 \mathrm{~m}^{2}$ was found to be as follows: Corbicula cor 1.8, C. fluminalis 1.2, C. purpurea 1.3, Corbiculina ferghanensis 2.6, C. tibetensis 2.9. Bivalve molluscs are divided into pelolimnophilic, peloreophilic and rheophilic groups according to their ecological groups. 8 types of peloreophiles in the muds of the Kummazor reservoir $66 \%$ (Sinanodonta gibba, S. orbicularis, S. puerorum, Corbicula cor, C. fluminalis, C. purpurea, Corbiculina ferghanensis, C. tibetensis), underwater muds, 2 types of pelolymophils in the mud 17\% (Colletopterum ponderosum volgense, S.kokandicum) reophilus 2 species $17 \%$ (Colletopterum bactrianum, C. cyreum sogdianum) live in stream waters.

We found that Corbicula cor, C. fluminalis, C. purpurea, Corbiculina ferghanensis, $C$. tibetensis are the most common eurybiont species in the aquatic ecosystems of the reservoir, and that the rest belong to stenabionts.

The Shurkul Reservoir is located in the lower part of the Zarafshan valley. The Shurkul Reservoir was commissioned in 1977 and has an average capacity of 170 million cubic meters. The reservoir receives water mainly from the Zarafshan River. The maximum height of the reservoir dam is $14.5 \mathrm{~m}$. The maximum discharge capacity of the reservoir is $350 \mathrm{~m}^{3} /$ sec. The Shurkul reservoir is home to 8 species and 2 subspecies of bivalve molluscs, which belong to 2 families and 4 seeds (Table 1). Chinese toothless Sinanodonta orbicularis, S. ruerorum The Shurkul Reservoir is being shown for the first time for mollusc fauna. They came to the reservoir as a result of acclimatization of Chinese complex fish - white amur (Ctenopharyngodon idella) and whitefish (Hypophthalmichthys molitrix). In Chinese complex fish, the larvae of Chinese toothless Sinanodonta seed gloxidia are parasitic. Living molluscs live at depths of 1.2 to 2.2 meters and more, with a density of Sinanodonta orbicularis 1.2, S. ruerorum 1.3. It crossed the Amudarya via the Amu-Bukhara canal to the basins of the Zarafshan River and through the Karshi main canal to the Tallimarjan Reservoir on the Kashkadarya River, leading to the spread of Sinanodonta seed species.

We can conclude that the influence of the Zarafshan River on the formation of the fauna of bivalve molluscs in the Shurkul reservoir is significant. Colletopterum cyreum sogdianum, C.bactrianum, C. ponderosum volgense species are widespread on the right and left banks of the reservoir, and their density is very low. Their density is 0.9 in Colletopterum cyreum sogdianum, 0.7 in Colletopterum bactrianum, and 0.8 in Colletopterum ponderosum 
volgense. Seasonal fluctuations in reservoir water levels affect the distribution of bivalve molluscs in biatopes. These species move very slowly and can move $15-20 \mathrm{~cm}$ in 1 hour.

\section{References}

1. Andrzej Kraszewski, Bogusław Zdanowski, Archives of Polish Fisheries, 9, 253-265 (2001)

2. G. P. Alyokhina, I.A. Misetov, M. V. Puzakova, Bulletin of the Orenburg State University, S(75), 181-185 (2007)

3. A. E. Bogan, Hydrobiologia, 595, 139-147 (2008).

4. V.V. Bogatov, Abstacts of the conference Mollusks of the Eastern Asia and Adjacents Seas, 6-12 (Vladivostok, 2014)

5. L.N. Yanovich, M.M. Pampura, Scientific Journal of the Uzhgorod State University, Biology Series, 32, 145-149 (2012)

6. O. P. Popa, Aquatic Invasions, 2(3), 265-267 (2007)

7. L.N. Yanovich, A.P. Stadnichenko, Parazitology, 4, 314-320 (1997)

8. S.P. Yarmonenko, Medical radiobiology. Radiation safety. 1, 30-36 (1998) 